\title{
Investigating the structure and reactivity of azolyl-based copper(I)- NHC complexes: the role of the anionic ligand
}

\author{
Michael Trose, ${ }^{\text {a }}$ Fady Nahra, ${ }^{\text {b }}$ Albert Poater, ${ }^{c, d}$ David B. Cordes, ${ }^{\text {a }}$ Alexandra M. Z. Slawin ${ }^{\text {a }}$, Luigi \\ Cavallo, ${ }^{\mathrm{c}}$ and Catherine S. J. Cazin ${ }^{\mathrm{a}, \mathrm{b}_{*}}$ \\ ${ }^{\text {a } E a S t C H E M ~ S c h o o l ~ o f ~ C h e m i s t r y, ~ U n i v e r s i t y ~ o f ~ S t ~ A n d r e w s, ~ S t ~ A n d r e w s, ~ K Y 16 ~ 9 S T, ~ U K ~}$ \\ ${ }^{\mathrm{b}}$ Ghent University, Department of Chemistry, Krijgslaan 281, S-3, B-9000 Ghent, Belgium \\ ${ }^{c}$ King Abdullah University of Science \& Technology, KAUST Catalysis Center (KCC), 23955-6900 Thuwal, Saudi Arabia \\ ${ }^{\mathrm{d}}$ Institut de Química Computacional i Catàlisi and Departament de Química, Universitat de Girona c/Maria Aurèlia Capmany \\ 6, 17003 Girona, Spain
}

Supporting Information Placeholder

ABSTRACT: A family of copper(I)-NHC azolyl complexes was synthetized and deployed in the hydrosilylation of dicyclo-
hexylketone to probe the role of the anionic ligand on catalytic performance. The azolyl ligand is shown to have a crucial role on
catalytic activity without the need for additives, and this at very low catalyst loading.
KEYWORDS: $N$-heterocyclic carbenes, copper(I), hydrosilylation, anionic ligand, dimer.

\section{INTRODUCTION}

During the last decade, copper(I)-NHC complexes have been intensively studied and used as catalysts in numerous organic transformations. ${ }^{1}$ Typically, the copper center in such complexes coordinates a NHC and an anionic ligand, forming a mononuclear linear neutral complex. ${ }^{2}$ Cationic mononuclear complexes, in which two NHCs are bound to the copper center, are also well-known. ${ }^{3}$ Dinuclear complexes with bridging or chelating ligands have also been reported although in significantly smaller numbers. Among these, dinuclear cationic complexes are the most common, typically formed by two copper(I) NHC fragments bridged by an anionic ligand such as hydride, ${ }^{4}$ fluoride, ${ }^{5}$ alkenyl ${ }^{6}$ and boryl ${ }^{7}$ with a general formula $\left[\mathrm{Cu}_{2}(\mu-\mathrm{X})(\mathrm{NHC})_{2}\right] \mathrm{Y}$. The neutral analogues possess a general formula $[\mathrm{Cu}(\mu-\mathrm{X})(\mathrm{NHC})]_{2}$ with a bridge acting simultaneously as anionic ligand to one copper center and neutral ligand to the other metal center. Examples of such bridges are silyl, ${ }^{8}$ sulfur, ${ }^{9}$ thiocyanate. ${ }^{10}$ Recently our group reported a new family of neutral dinuclear copper(I)-NHC complexes 1 bearing 1,2,4-triazole (trz) as anionic ligand (Figure 1). These complexes were shown to be highly active in the hydrosilylation of ketones, affording the corresponding alcohols in excellent yields, without the need for external additives. ${ }^{11}$ Among these complexes, complex 1a containing trz and IPr (IPr = N, N'-bis[(2,6-(di-isopropyl)phenyl)]imidazol-2-ylidene]) ligands proved to be the best catalyst, converting a wide range of ketones into the corresponding alcohols, with a catalyst loading as low as 0.05 mol\%. Such complexes were shown to be dimers in the solid state, with trz bridging the two copper centers. In this previous report, different NHCs were affixed to the copper centers and their reactivity compared.

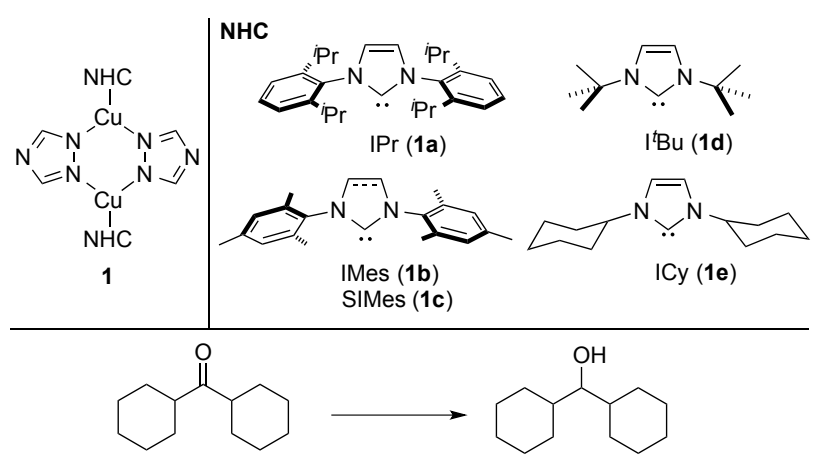

Method A i) $\left[\mathrm{Cu}(\mu \text {-trz)(IPr) }]_{2} 1 \mathrm{a}(0.05 \mathrm{~mol} \%), \mathrm{Me}(\mathrm{OEt}){ }_{2} \mathrm{SiH}, \mathrm{THF}, 55^{\circ} \mathrm{C}, 2 \mathrm{~h}\right.$; ii) TBAF, MeOH, RT, $45 \mathrm{~min} .95 \%$.

Method B i) $\left[\mathrm{Cu}(\mu \text {-trz)(IPr) }]_{2} 1 \mathrm{a}(0.25 \mathrm{~mol} \%), \mathrm{PMHS}, \mathrm{THF}, 55^{\circ} \mathrm{C}, 14 \mathrm{~h}\right.$; ii) $\mathrm{MeOH}, \mathrm{NaOH} 2 \mathrm{M}, \mathrm{RT}, 90 \mathrm{~min} . \mathbf{9 7 \%}$.

Low catalyst loading $\cdot$ No additive $\cdot$ Wide scope

Figure 1. Copper(I)-NHC complexes $[\mathrm{Cu}(\mu-\operatorname{trz})(\mathrm{NHC})]_{2}$ and their application in the hydrosilylation of ketones. ${ }^{11}$

Considering the unusual coordination observed in this new class of compounds, and their outstanding catalytic performance, we were interested in investigating how variation of the azolyl fragment would affect coordination chemistry and catalysis. Herein we report the synthetic access to a library of derivatives of the form $[\mathrm{Cu}(\text { azolyl })(\operatorname{IPr})]_{\mathrm{n}}(\mathrm{n}=1$ or 2), their catalytic activity as well as mechanistic studies to elucidate the key parameters responsible for the high activity showed by $\left[\mathrm{Cu}(\mu \text {-trz)(IPr) }]_{2}\right.$ (1a) and its novel congeners. 


\section{RESULTS AND DISCUSSION}

Synthesis and characterization of NHC azolyl complexes. The desired complexes were obtained by reacting $[\mathrm{Cu}(\mathrm{Cl})(\mathrm{IPr})]^{2 \mathrm{~d}}(\mathbf{2})$ with cesium hydroxide in the presence of the corresponding azole. The synthesis was performed on a 1 gram scale and good to excellent yields were obtained for all selected azoles (Table 1). All complexes were fully characterized by NMR spectroscopy, elemental analysis and $\mathrm{X}$-Ray diffraction. With the exception of 3a, all are air- and moisture-stable in the solid state. ${ }^{12}$

Table 1. Synthesis of $[\mathrm{Cu}(\text { azolyl })(\mathrm{IPr})]_{\mathrm{n}}$ complexes $^{\mathrm{a}}$

\begin{tabular}{|c|c|c|c|c|}
\hline \multicolumn{3}{|c|}{$\begin{array}{l}{[\mathrm{CuCl}(\mathrm{IPr})]+2 \mathrm{CsOH}+\text { azole }} \\
\quad 2\end{array}$} & \multicolumn{2}{|r|}{$\begin{array}{c}{[\mathrm{Cu}(\mu \text {-azole })(\mathrm{IPr})]_{2}} \\
\text { 3a-c } \\
\text { or } \\
{[\mathrm{Cu}(\text { azole })(\mathrm{IPr})]} \\
\text { 3d-f }\end{array}$} \\
\hline Entry & Azole & Comples & & $\begin{array}{l}\text { Yield } \\
(\%)^{b}\end{array}$ \\
\hline 1 & & {$[\mathrm{Cu}(\mu-\mathrm{p}$} & $(\operatorname{IPr})]_{2} \mathbf{3 a}$ & 81 \\
\hline 2 & & $\begin{array}{l}{[\mathrm{Cu}\{\mu-(} \\
\mathbf{3 b}\end{array}$ & $-\mathrm{Me}-\mathrm{prz})\}(\mathrm{IPr})]_{2}$ & 85 \\
\hline 3 & & {$[\mathrm{Cu}\{\mu-($} & -Br-prz) $\}(\operatorname{IPr})]_{2} \mathbf{3 c}$ & 93 \\
\hline 4 & & {$[\mathrm{Cu}(3-\mathrm{M}$} & $-p r z)(\operatorname{IPr})]$ 3d & 92 \\
\hline 5 & & {$[\mathrm{Cu}(3-\mathrm{B}$} & -prz)(IPr)] 3e & 90 \\
\hline 6 & & {$[\mathrm{Cu}$ (ind) } & IPr)] $\mathbf{3 f}$ & 94 \\
\hline
\end{tabular}

${ }^{a}$ Reaction conditions: $[\mathrm{Cu}(\mathrm{Cl})(\mathrm{NHC})](1 \mathrm{~g})$, azole (1.1 equiv.), $\mathrm{CsOH}$ (2.0 equiv.), solvent $(20 \mathrm{~mL}), \mathrm{RT}, 16 \mathrm{~h}$, under argon. ${ }^{\mathrm{b}}$ Isolated yield.

As a function of the azole used, two coordination modes were observed in the solid state as determined by X-ray diffraction analysis: 1) dinuclear complexes bridged by the azole or 2) mononuclear complexes with the azole as a monodentate anionic ligand (Figure 2). Dinuclear structures were obtained when the non-substituted azole (3a) was used or when the substituents were far away from the coordinating nitrogen (3b and $\mathbf{3 c}$ ); with these complexes, each copper atom displayed a distorted trigonal geometry. Contrarily, when the azole contains a steric hindrance closer to the metalcoordination site (3d-3f), mononuclear complexes were favored; in these cases, the copper atom showed an almost linear geometry for the $\mathrm{C}_{\mathrm{NHC}}-\mathrm{Cu}-\mathrm{N}_{\text {azolyl }}$ fragment (3d, $\left.176.8(8)^{\circ} ; 3 \mathbf{e}, 177.20(18)^{\circ} ; \mathbf{3 f}, 172.30(8)^{\circ}\right)$. As expected, the $\mathrm{C}_{\mathrm{NHC}}-\mathrm{Cu}$ distances are slightly longer in the dimeric (3a,

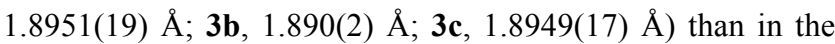
monomeric species (3d, 1.8281(19) $\AA$; 3e, 1.872(4) $\AA$; 3f, $1.8070(2) \AA)$. Moreover the $\mathrm{C}_{\mathrm{NHC}}-\mathrm{Cu}$ bond lengths in 3a-3c are comparable with the triazole analogue 1a (1.896(2) $\AA$ ).
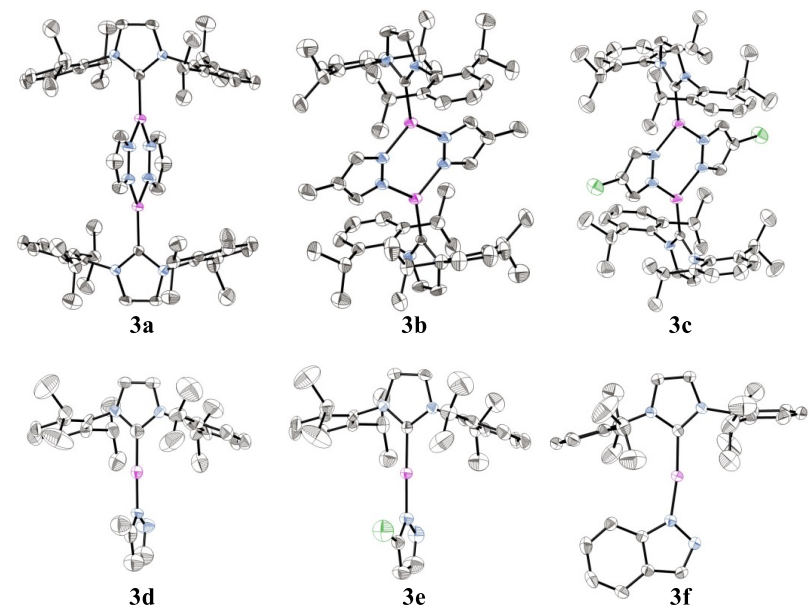

Figure 2. Molecular structures of 3a-3f. Solvent molecules are omitted for clarity. Thermal ellipsoids are shown at $50 \%$ probability. Hydrogens are omitted for clarity.

Comparison of $[\mathrm{Cu}(\text { azolyl })(\mathrm{NHC})]_{\mathrm{n}}$ complexes in the hydrosilylation of dicyclohexylketone. The new complexes were tested in the hydrosilylation of ketones using the optimal conditions previously reported ${ }^{11}(0.05 \mathrm{~mol} \%$ catalyst loading, THF, $55{ }^{\circ} \mathrm{C}, 1.1$ equiv. of methyldiethoxysilane as hydride source) in order to investigate the effect of the azole ligands on catalysis. As a benchmark substrate, the hindered dicyclohexylketone was chosen and a reaction profile for each complex was obtained (Figure 3). The reaction profiles showed two main trends: firstly, all complexes require an induction period prior to catalysis, commonly $5 \mathrm{~min}$ (except $3 \mathbf{e}$ - $10 \mathrm{~min}$ ). Secondly, all catalysts lead to quantitative conversion (Except 3e, 97\%) although in different reaction time. Within the pyrazole series, a trend correlating reaction rate and electronic properties of the substituent on the ring is found. Indeed, catalysts bearing an electron donating group on the pyrazolyl ligand ( $[\mathrm{Cu}\{\mu \text {-(4-Me-prz) }\}(\mathrm{IPr})]_{2} \mathbf{3 b}$ and $[\mathrm{Cu}(3-$ Me-prz)(IPr)] 3d) led to rapid conversion of the substrate while reaction rates using derivatives containing an electron withdrawing group on the pyrazol ring were slower $([\mathrm{Cu}\{\mu-(4-$ Br-prz) $\}(\mathrm{IPr})]_{2}$ 3c, $[\mathrm{Cu}(3-\mathrm{Br}-$ prz)(IPr) $]$ 3e). In contrast, no trend can be found between catalytic activity and steric properties of the ligands and hence complexes' nuclearity as opposite reactivity was observed when comparing complexes $\mathbf{3 c} / \mathbf{3 e}$ to complexes $\mathbf{3 b} / \mathbf{3 d}$; in the former pair, the 4-bromosubstituted azole-based complex (3c) was the most active catalyst, and in the latter pairing, the 3-Me-substituted azolebased complex (3d) outperformed the 4-Me-substituted analogue (3b). In this context, electronic parameters seem to govern catalyst reactivity. Nevertheless, all azole derivatives perform well in this hydrosilylation reaction, notably with $\mathbf{3 d}$ reaching $85 \%$ conversion at $55{ }^{\circ} \mathrm{C}$ within 10 min using a catalyst loading of $0.05 \mathrm{~mol} \%$ ). Interestingly, the fastest 
reaction rate was observed with the indazole derivative [Cu(ind)(IPr)] 3f, with $90 \%$ conversion reached within $10 \mathrm{~min}$ and full conversion within $20 \mathrm{~min}$. This is a significant improvement over 1a which requires 60 minutes to reach full conversion.

These catalytic studies demonstrate that, in addition to governing the nuclearity of the complexes, the azole moiety plays an important role during catalysis. Mechanistic studies were therefore undertaken in order to get insights on the role played by the different components of the catalytic system.

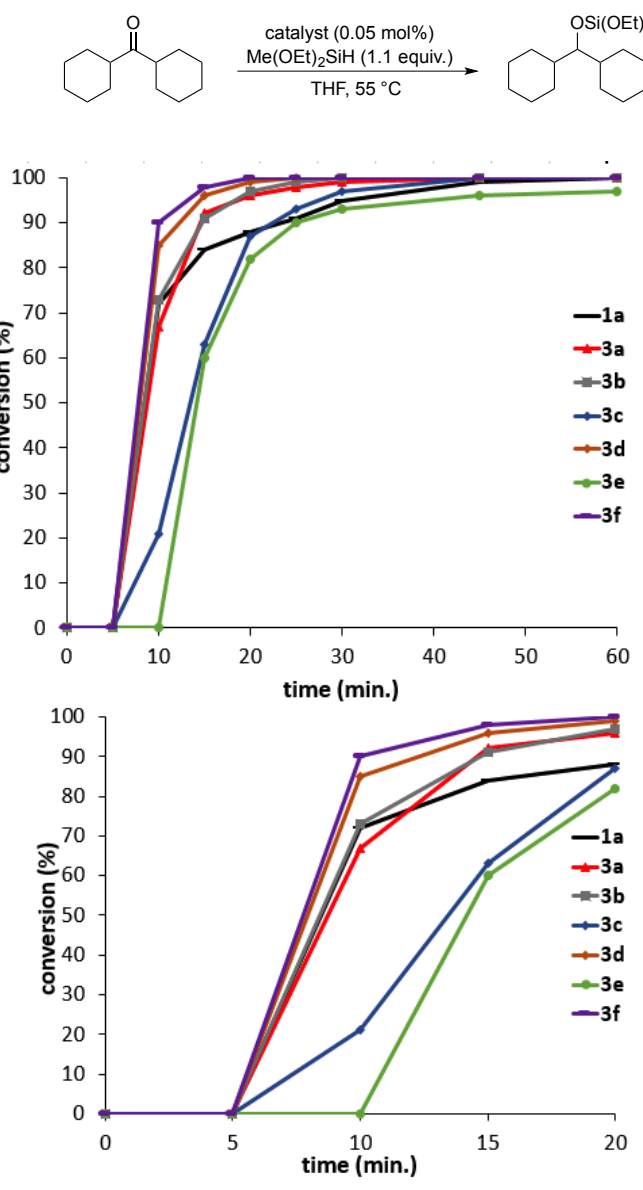

Figure 3. Reaction profile of the hydrosilylation of dicyclohexyl ketone catalyzed by copper(I)-NHC azole complexes (top). Expansion of $0-20 \mathrm{~min}$. range in order to clarify the different induction time detected (bottom). Conversion determined by GC, based on dicyclohexyl ketone, average of 2 reactions.

Mechanistic studies. The following studies were undertaken to probe the reasons behind the influence of the nature of the azolyl ligand. The copper-catalyzed hydrosilylation of ketones ${ }^{13}$ has been intensively studied with various cationic and neutral copper(I)-NHC pre-catalysts ${ }^{14}$ and the accepted catalytic cycle consists of: 1) the copper precatalyst reacting with the hydrosilane to form a copper hydride active species, 2) subsequent addition of the copper hydride to the ketone affords a copper alkoxide intermediate, 3) $\sigma$-bond metathesis of the latter species with another hydrosilane molecule liberates the corresponding silylether, regenerating the copper hydride and thus closing the catalytic cycle (Scheme 1). ${ }^{15}$ In order to understand whether $[\mathrm{Cu}(\mu-$ azolyl)(NHC) $]_{2}$ complexes behave in accordance with the aforementioned cycle, we investigated each step using 1a as the model pre-catalyst.

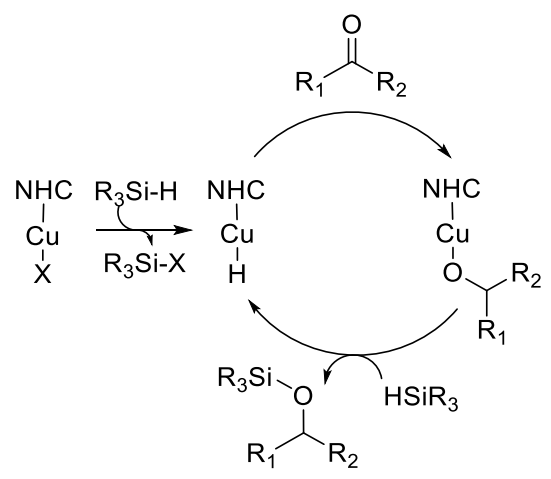

Scheme 1. General accepted mechanism for the hydrosilylation of ketones catalyzed by copper(I)-NHC complexes.

Behavior of $[\mathrm{Cu}(\mu \text {-trz })(\mathrm{IPr})]_{2}$ in the solid state and in solution. A peculiarity encountered with this family of complexes lies in their dinuclear nature in the solid state due to the triazole bridge. With the purpose of understanding their behavior in solution, ${ }^{1} \mathrm{H}$ DOSY NMR spectroscopy experiments were carried out on 1a to establish its diffusion coefficient and to correlate this value to its predicted molecular weight (Table 2). ${ }^{16}$ Based on these experiments, the predicted molecular weight was shown to be similar to the calculated value of the monomer $\left(520 \mathrm{~g} \mathrm{~mol}^{-1}\right)$, independently of the polarity of the solvent, indicating the lability of the azole bridge in solution.

Table 2. Diffusion coefficients (D) and predicted molecular weights (MW) for complex $1 \mathrm{a}$.

\begin{tabular}{cccc}
\hline Entry & Solvent & $\mathrm{D}\left(\mathrm{m}^{2} / \mathrm{s}\right)$ & $\mathrm{MW}(\mathrm{g}$ mol-1) \\
\hline 1 & THF- $d_{8}$ & $9.84875 \mathrm{E}-10$ & 478.2 \\
2 & $\mathrm{C}_{6} \mathrm{D}_{6}$ & $6.85494 \mathrm{E}-10$ & 561.5 \\
\hline
\end{tabular}

Investigation of the catalytic cycle and of the formation of the copper hydride. Two mechanistic scenarios can be envisaged for the formation of the copper hydride species, depending on the nature of the pre-catalyst: 1) direct $\sigma$ metathesis of the pre-catalyst with the hydrosilane, without the need for external additives (pathway taken with pre-catalysts such as tert-butoxide ${ }^{17}$ or bifluoride ${ }^{18}$ complexes); or 2) preactivation of the pre-catalyst is needed using external additives such as tert-butoxide bases, due to lack of direct reactivity with the silane (pathway taken with halide-based complexes). ${ }^{2 \mathrm{c}, 3 \mathrm{a}, 14 \mathrm{~b}, \mathrm{c}}$ As mentioned earlier, 1a catalyzes the hydrosilylation of ketones without any additive. In this 
context, a stoichiometric reaction between $\mathbf{1 a}$ and methyldiethoxysilane was performed; however, no evidence of the formation of the expected hydride was detected by ${ }^{1} \mathrm{H}$ NMR spectroscopy, even when the sample was heated at 55 ${ }^{\circ} \mathrm{C}$ (Scheme 2). Since the reaction between hydrosilanes and copper precursors active in hydrosilylation reactions is usually spontaneous, ${ }^{17}$ this lack of reactivity was unexpected. The fact that the reported catalytic reaction with 1a does not proceed at room temperature and that a temperature of $55{ }^{\circ} \mathrm{C}$ is needed for it to occur is also unconventional for these types of additive-free catalysts. $^{11}$ In contrast, upon addition of acetophenone $\mathbf{4}$ to the mixture of $\mathbf{1 a}$ and methyldiethoxysilane, conversion toward the corresponding silylether 5 was observed, indicating that both silane and ketone are needed in order to initiate the reaction (see ESI, Figure S8). In this context, we postulate that ketone 4 might be reduced by the silane at $55{ }^{\circ} \mathrm{C}$ to generate the silylether 5 . Most likely, this is assisted by $\mathbf{1 a}$ to form a possible tight-ionpair silicate hydride species $\left([\mathrm{Cu}(\mathrm{IPr})]^{+}\left[\mathrm{H}-\mathrm{SiR}_{3}(\operatorname{trz})\right]^{-}\right)$which can subsequently react with $\mathbf{4}$ to form $\mathbf{5} .^{15 b, 18}$ Even though such silicate was not detected in the NMR tests when mixing 1a with the silane (Scheme 2), it is possible that it exists in equilibrium. That equilibrium could then shift towards the formation of 5 in the presence of ketone 4. Previous DFT calculations by the Riant and Leyssens groups offer support to the silicate formation. ${ }^{15 b, 18}$ It should be noted that only a small amount of $\mathbf{5}$ is needed for the catalyst initiation and since $\mathbf{5}$ is also formed after each catalytic cycle, a build-up of the latter compound gradually accelerates the initiation step, rendering the whole system autocatalytic. This is further supported by the presence of an induction period (see Figure 3), which can be attributed to the autocatalytic initiation step. Subsequently, silylether 5 reacts with 1 a, leading to the formation of the copper alkoxide intermediate $\mathbf{6}$, which in turn reacts with the silane to form the key copper hydride intermediate 7 . This hypothesis was confirmed by stoichiometric reactions where isolated copper(I)-NHC alkoxide $\mathbf{6}$ was reacted with methyldiethoxysilane, leading to the quantitative formation of the silylether $\mathbf{5}$ and the $\mathrm{Cu}$-hydride $\mathbf{7}$ (characteristic hydride resonance $\delta_{\mathrm{H}} 2.61 \mathrm{ppm}$ ). An alternative pathway involving the formation of a $\mathrm{Cu}-\mathrm{NHC}$ enolate intermediate capable of activating the silane to form the hydride complex 7 was considered; however, this possibility was ruled out considering that 1) no reaction occurs between the $\mathrm{Cu}$ complex $1 \mathrm{a}$ and the ketone 4 in the absence of silane, and 2) the stoichiometric reaction of 1a with benzophenone and methyldiethoxysilane also afford the corresponding silylether (Scheme 2). While the reaction of 1a with silylether 5 did not afford the expected (vide supra) copper alkoxide $\mathbf{6}$, reaction of the latter with a mimic of the silylated triazole by-product formed during catalyst activation led to the formation of 1a. Indeed, the stoichiometric reaction between $\mathbf{6}$ and 1-trimethylsilyl-1,2,4triazole (TMS-trz) ${ }^{19}$ generates 1a (Scheme 3), hence supporting the hypothesis of a dynamic process existing between these species during the catalysis. The fact that at room temperature this equilibrium is completely shifted toward 1a accounts for the lack of catalytic activity of the latter at this temperature. However, even though the formation of $1 \mathbf{a}$ is favored, the generation of an appreciable amount of $\mathbf{6}$ would be enough to shift the equilibrium toward the formation of 5 , thus effectively enabling the catalytic reaction.

In order to gain a better understanding of the inner working of the reaction under catalytic conditions, reaction profiles of the hydrosilylation of $\mathbf{4}$ catalyzed by [Cu(ind)(IPr)] 3f, $[\mathrm{Cu}(1-$ phenylethoxy)(IPr) $] \quad$ 6, $\quad\left[\mathrm{Cu}(\mu \text {-trz)(IPr) }]_{2} \quad \mathbf{1 a}, \quad\right.$ and $\left[\mathrm{Cu}\left(\mathrm{O}^{t} \mathrm{Bu}\right)(\mathrm{IPr})\right] \mathbf{8}$ were recorded (Figure 4). In accordance with previous observations, complexes of the type $[\mathrm{Cu}(\text { azole })(\mathrm{IPr})]_{\mathrm{n}}$ lead to a substantial induction period. In marked contrast, [Cu(1-phenylethoxy)(IPr)] $\mathbf{6}$ leads to a very rapid rate of reaction without any induction. Furthermore, addition of the silyl triazole TMS-trz to $[\mathrm{Cu}(1-$ phenylethoxy)(IPr)] 6 (trz: $\mathrm{Cu} 1: 1$ ) leads to a dramatic drop of reaction rate in addition to a substantial induction period. These observations point to the presence of an off-cycle equilibrium between 1a and $\mathbf{6}$ that would affect both initiation step and reaction rate, since only complex $\mathbf{6}$ is able to form the hydride derivative 7 which is presumed to be the active catalyst.

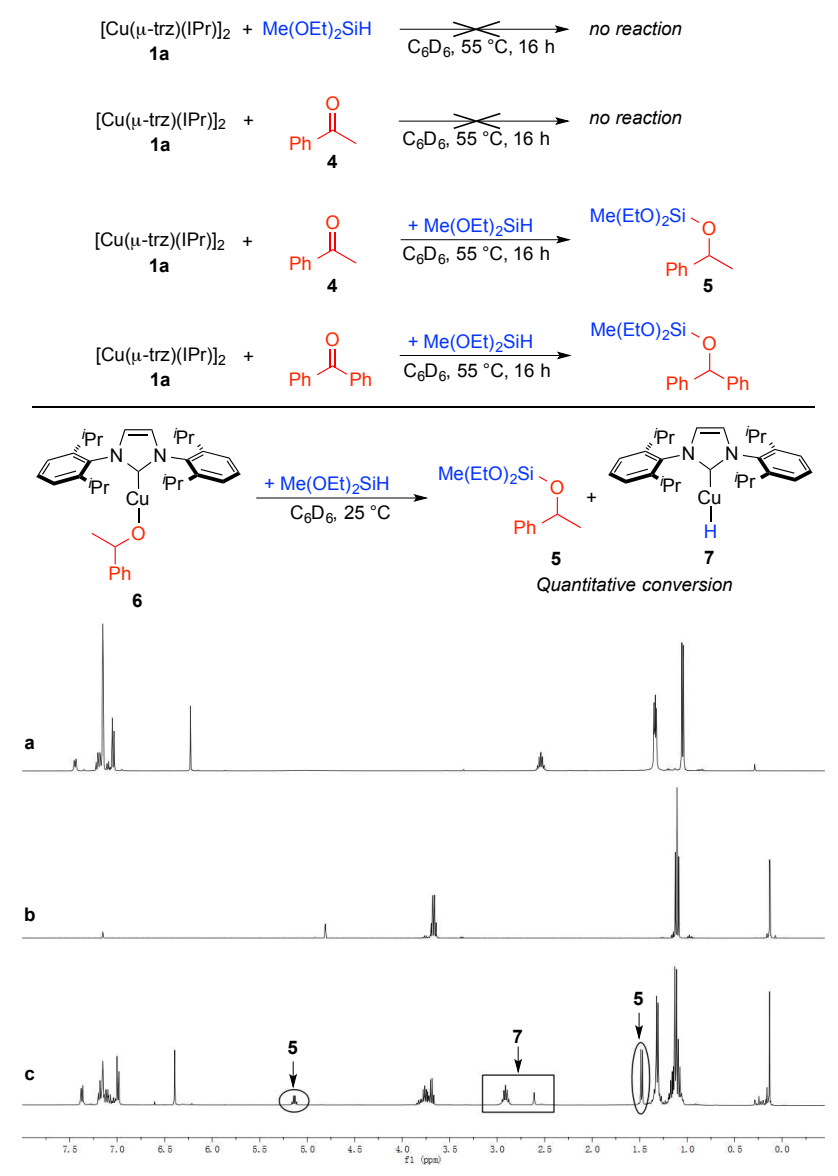

Scheme 2. ${ }^{1} \mathrm{H}$ NMR spectra of stoichiometric reactions a) complex 6, b) $\left.\mathrm{HSiMe}(\mathrm{OEt})_{2}, \mathbf{c}\right) \mathbf{6}+\mathrm{HSiMe}(\mathrm{OEt})_{2}$. 


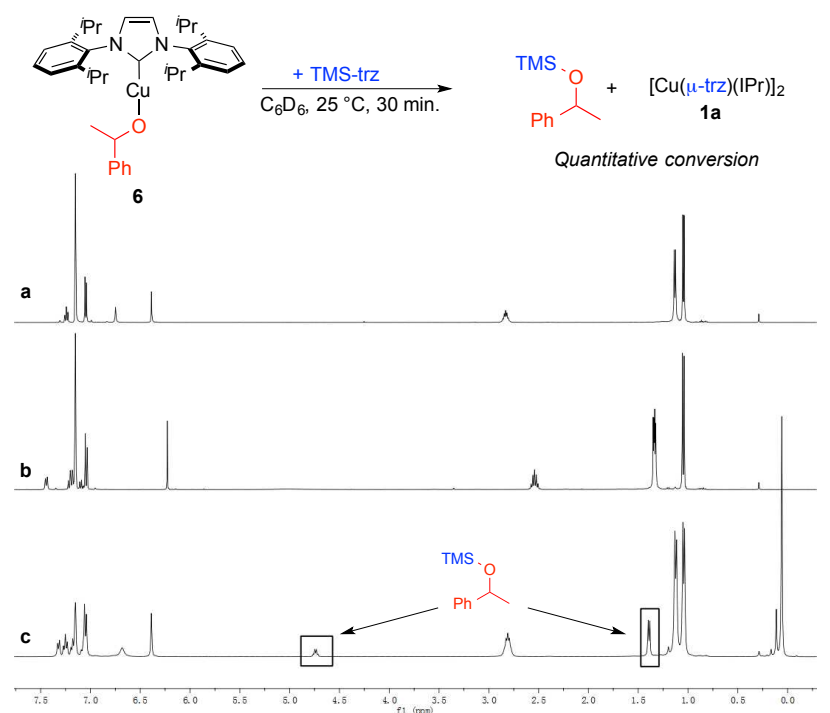

Scheme 3. ${ }^{1} \mathrm{H}$ NMR spectra of stoichiometric reactions: a) complex 1a, b) complex 6, c) $6+$ TMS-trz, $25^{\circ} \mathrm{C}, 30 \mathrm{~min}$.

Kinetic profiling involving $\left[\mathrm{Cu}\left(\mathrm{O}^{t} \mathrm{Bu}\right)(\mathrm{IPr})\right] \mathbf{8}$, a common precursor to $[\mathrm{Cu}(\mathrm{H})(\mathrm{IPr})]$, was also undertaken. These experiments show that the in situ catalyst $\left(2+\mathrm{NaO}^{t} \mathrm{Bu}\right)$ is not active under these conditions, and that the well-defined complex $\mathbf{8}$ is much less efficient than the azole dimer 1a and the phenylethoxy intermediate 6 (Figure 4). This drop in efficiency might be due to an off-cycle equilibrium between 6 and $\mathbf{8}$, similarly to $\mathbf{1 a}$. It should be noted that $\mathbf{8}$ did not require any induction time, which was expected considering its known reactivity with silanes to quickly form hydride species and its close kinship to the alkoxide congener $\mathbf{6}$. These data underline the non-innocent role of the alkoxide fragment in the catalytic process.

Based on these observations, a proposed catalytic cycle is presented in Scheme 4 - with either $[\mathrm{Cu}(\mu \text {-trz })(\mathrm{IPr})]_{2} \mathbf{1 a}$ as the pre-catalyst or $\left[\mathrm{Cu}\left(\mathrm{O}^{t} \mathrm{Bu}\right)(\mathrm{IPr})\right] \mathbf{8}$. When 1a is used, the first step (I) of the reaction consists of dissociation of $[\mathrm{Cu}(\mu-$ trz)(IPr) $]_{2}$ to its monomeric form [Cu(trz)(IPr)], followed by a reaction with a small amount of 5 formed at $55{ }^{\circ} \mathrm{C}$ (II), leading to the formation of the intermediate complex $[\mathrm{Cu}(1-$ phenylethoxy)(IPr)] 6. The latter reacts rapidly with the silane (step III) to form the active hydride derivative 7. In contrast, when complex $\mathbf{8}$ is used as a pre-catalyst, the system enters the catalytic cycle directly through this step (III). Once hydride 7 is generated, it can react with the ketone to regenerate 6 (step IV). Subsequent $\sigma$-bond metathesis of $\mathbf{6}$ with another molecule of silane liberates the desired product $\mathbf{5}$, thus closing the catalytic cycle (step V). The presence of off-cycle equilibria accounts for the discrepancy observed in the rate of reactions when comparing pre-catalysts $(6>>1 a>8)$. Indeed, such equilibria decrease the concentration of active species present in the catalytic reaction, hence decreasing the rate of the reaction. This issue can be addressed by tuning the anionic ligand, as shown in Figure 4, where [Cu(ind)(IPr)] 3f performs as well as $[\mathrm{Cu}(1-$ phenylethoxy)(IPr) $]$ 6, despite a short induction period.
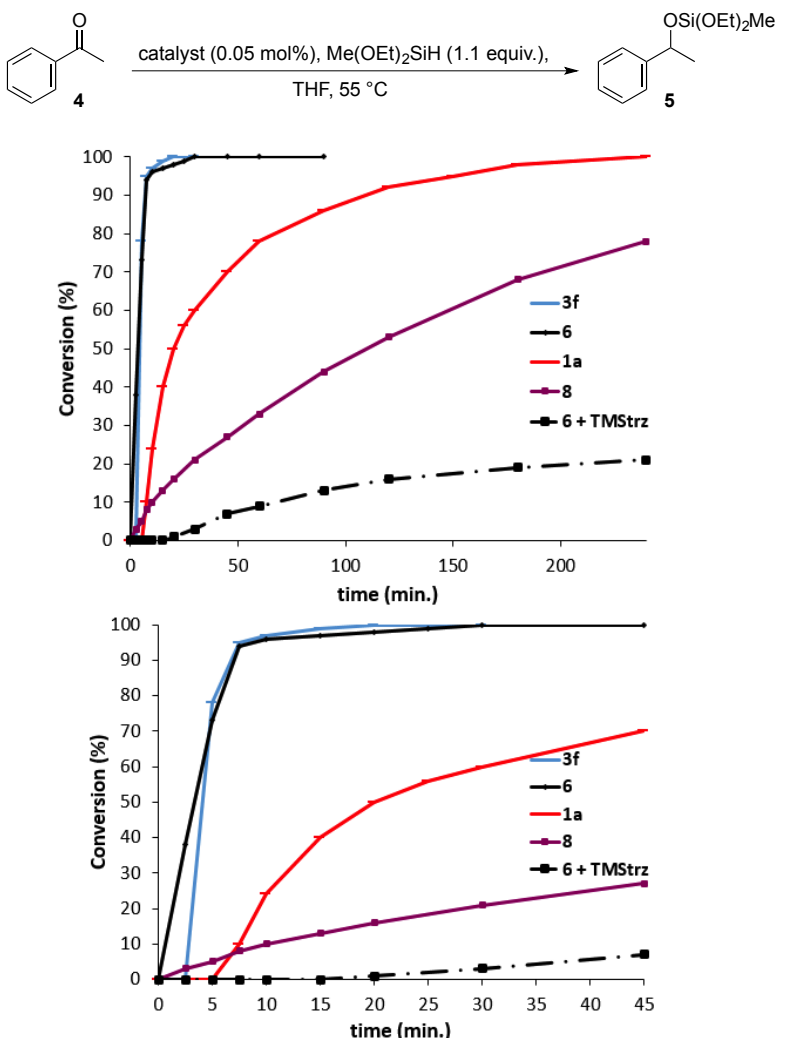

Figure 4. Reaction profiles of the catalytic hydrosilylation of acetophenone (top). Expansion of 0-50 min. range (bottom). Conversion determined by GC, based on acetophenone, average of 2 reactions.

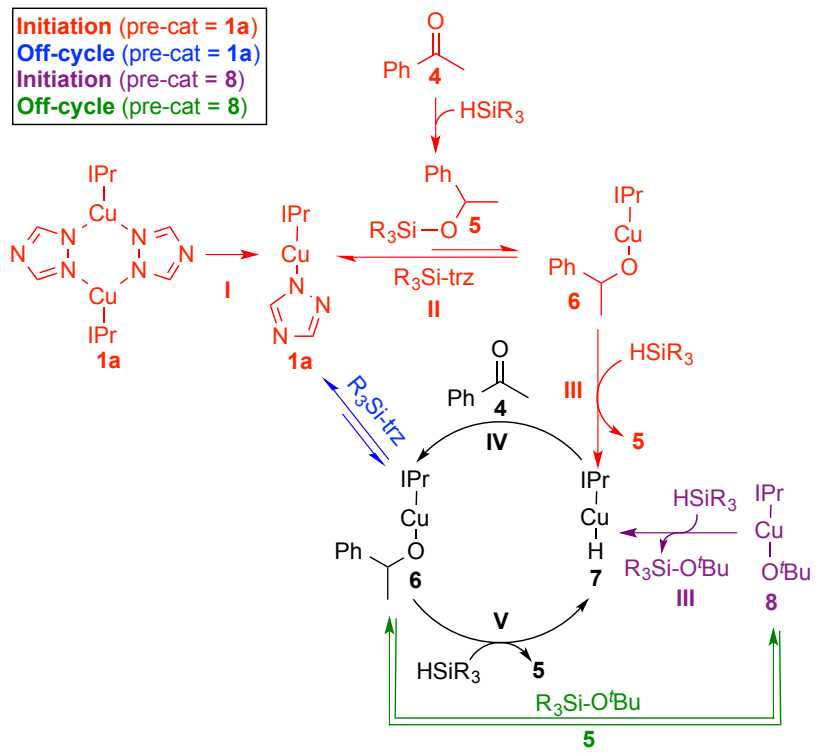

Scheme 4. Proposed mechanism for the hydrosilylation of acetophenone. 
Influence of the NHC ligand. In order to gain further mechanistic insights, the role of the N-heterocyclic carbene (NHC) ligand was next examined. As shown in our first report on species of the type $[\mathrm{Cu}(\mu \text {-trz })(\mathrm{NHC})]_{2}$, while complexes bearing $N$-aryl NHC ligands led to outstanding catalyst activity, $N$-alkyl substituted analogues were not active. ${ }^{11}$ In order to understand this peculiar difference, density functional theory (DFT) calculations were undertaken. Following the mechanistic insights described in Scheme 4, the mechanism for 1a was modeled using the hindered dicyclohexyl ketone and methyldiethoxysilane as a model substrates. Particular attention was paid to the step involving hydride addition to the approaching ketone (IV) as we found that steps leading to the formation of the hydride (III) as well as the regeneration of the catalytic active species by a new silane molecule $(\mathbf{V})$ were significantly less energetically demanding. The energy barrier corresponding to the transition state for step IV was located at $29.9,28.5,28.4,35.3$ and $33.2, \mathrm{kcal} / \mathrm{mol}$ for systems $\mathbf{1 a - 1 e}$, respectively (Table 3 ).

Table 3. Energy (Kcal/mol) of the transition state for step IV.

\begin{tabular}{cccccc}
\hline$\left[\mathbf{C u}(\boldsymbol{\mu} \text {-trz)(NHC) }]_{\mathbf{2}}\right.$ & $\mathbf{1 a}$ & $\mathbf{1 b}$ & $\mathbf{1 c}$ & $\mathbf{1 d}$ & $\mathbf{1 e}$ \\
$\mathrm{NHC}$ & IPr & IMes & SIMes & ItBu & ICy \\
& & & & & \\
\hline $\mathrm{E}_{(\mathrm{TS}-\mathrm{IV})}$ & 29.9 & 28.5 & 28.4 & 35.3 & 33.2 \\
\hline
\end{tabular}
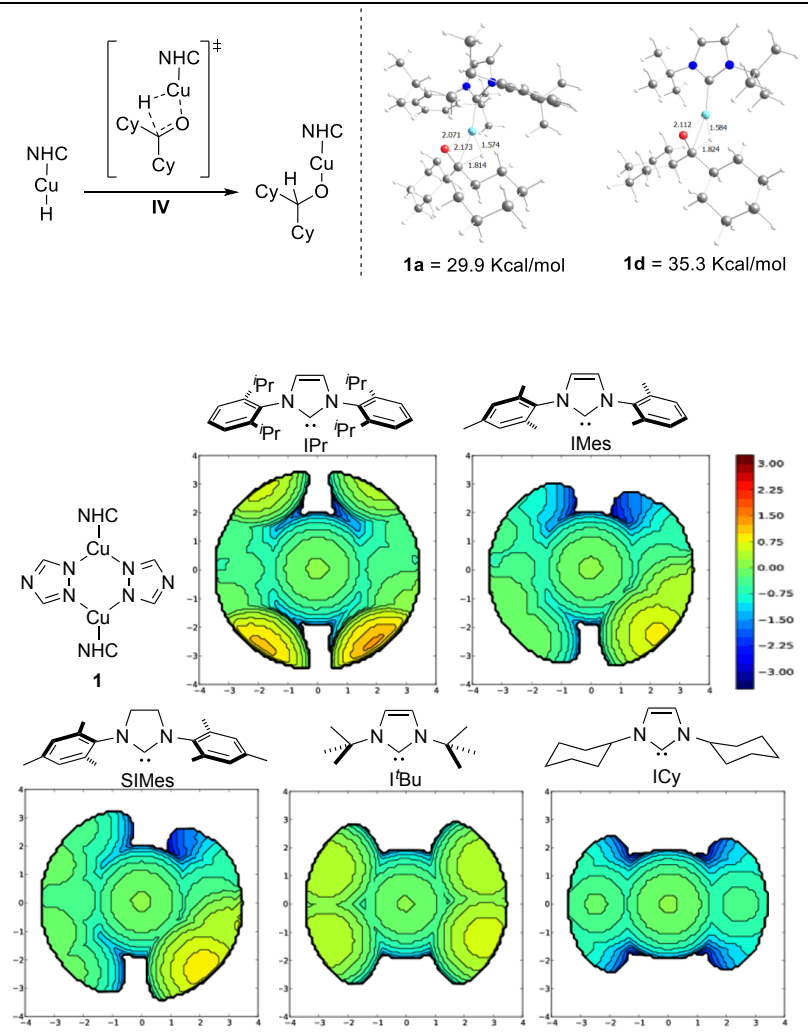

Figure 5. Topographic steric maps for the NHC ligands of complexes 1a-1e. $\% V_{\text {Bur }}$ is the percent of buried volume. The $\mathrm{Cu}$ atom is at the origin and the $\mathrm{C}_{\mathrm{NHC}}$ is on the $\mathrm{z}$ axis. The isocontour curves of the steric maps are given in $\AA$.

The significantly lower energy barriers in the rate-determining step for 1a-1c relative to $\mathbf{1 d - 1 e}$ are thus fundamental in understanding the lack of reactivity of the latter systems (no catalytic reaction was observed using catalysts $\mathbf{1 d - 1 e )}{ }^{11}$ The steric hindrance around the metal due to the $\mathrm{NHC}$, as determined by the $\% V_{\text {Bur }}$ values $(44.4,39.2,40.1,42.1$ and 29.0 for 1a-1e, respectively), does not show a clear correlation with the reactivity of these complexes. Nevertheless, steric maps displayed in Figure 5 describe a significant difference between the two sets of systems. ${ }^{20}$ Equal steric hindrance around the metal for systems 1a-1c is observed. In contrast, systems 1d and 1e show a "hole" corresponding to the cleft between the two $\mathrm{Cy}$ and both ${ }^{t} \mathrm{Bu} N$-substituents, respectively. ${ }^{21}$ As steric properties play an important role in the step involving $\mathrm{H}$-transfer to the ketone, it is likely that these clefts in steric hindrance observed with ItBu and ICy are responsible for the lack of reactivity of the related complexes. $^{22}$

\section{CONCLUSION}

A series of copper(I)-NHC complexes bearing an azole moiety has been synthetized ${ }^{23}$ and deployed in the hydrosilylation of dicyclohexylketone and acetophenone, as test reactions. This variation allows for the evaluation of the azolyl ancillary ligand effect on catalytic activity. Improved catalytic performance, compared to that reported for $\mathbf{1}$, was achieved by variation of the azole ligand (3d and 3f). Mechanistic studies permit the determination of the presence of an off-cycle equilibrium between $1 \mathbf{a}$ and the active alkoxide 6, accounting for the different reactivity among the various pre-catalysts. The superior activity of $\mathbf{3 f}$ clearly showcases that this class of compounds can be fine-tuned to achieve very high activity, acting without additive, and retaining the stability of $\mathbf{1 a}$.

In summary, not only the neutral NHC ancillary ligand about the pre-catalyst but also the anionic moiety plays a significant role in leading to effective catalysts operating at very low catalyst loading $(0.05 \mathrm{~mol} \%)$ without any additives. Further studies along these lines are ongoing and will be reported in due course.

\section{EXPERIMENTAL SECTION}

General considerations: All reactions were carried out under inert atmosphere using a glovebox or standard Schlenk techniques. All reagents were purchased and used as received. All solvents were dried before use. ${ }^{1} \mathrm{H}$ and ${ }^{13} \mathrm{C}-\left\{{ }^{1} \mathrm{H}\right\}$ Nuclear Magnetic Resonance (NMR) spectra were recorded at $298 \mathrm{~K}$ on a Bruker Advance 400 Ultrashield or on a Bruker Advance 500 Ultrashield spectrometer using the residual solvent peak $\left(\mathrm{CD}_{2} \mathrm{Cl}_{2}: \delta \mathrm{H}=5.30 \mathrm{ppm}, \delta \mathrm{C}=53.52 \mathrm{ppm} ; \mathrm{C}_{6} \mathrm{D}_{6}\right.$ : $\delta \mathrm{H}=7.15 \mathrm{ppm}, \delta \mathrm{C}=128.62 \mathrm{ppm})$. Elemental analysis was performed by London Metropolitan University. Gas chromatography (GC) analyses were performed on an Agilent 7890A apparatus equipped with a flame ionization detector and a (5\%-phenyl)methylpolysiloxane column ( $30 \mathrm{~m}, 320 \mu \mathrm{m}$, film: $0.25 \mu \mathrm{m})$.

General procedure for the synthesis of [Cu(azole)(NHC)] 
complexes. In a glovebox, a $50-\mathrm{mL}$ round-bottomed flask was charged with $[\mathrm{Cu}(\mathrm{Cl})(\mathrm{NHC})](1 \mathrm{~g}, 1.0$ equiv.), azole (1.1 equiv.), $\mathrm{CsOH}(2.0$ equiv.) and THF $(20 \mathrm{~mL})$. The reaction was stirred at 25 ${ }^{\circ} \mathrm{C}$ for $16 \mathrm{~h}$. The solution was filtered through Celite which was washed $\left(\mathrm{CH}_{2} \mathrm{Cl}_{2}, 3 \times 5 \mathrm{~mL}\right)$. The organic phases were combined and the mixture was concentrated in vacuo until formation of a precipitate. Pentane $(20 \mathrm{~mL})$ was added. The precipitate was collected by filtration, washed with pentane $(2 \times 5 \mathrm{~mL})$ and dried in vacuo.

Bis-\{[N,N'-bis(2,6-(di-isopropyl)phenyl)imidazol-2-ylidene] $(1 \mathrm{H}$ 1,2,4-triazol-1-yl)\}copper (I), $\left[\mathrm{Cu}(\mu \text {-trz) }(\mathrm{IPr})]_{2}, \mathbf{1 a}\right.$. Reaction between $[\mathrm{Cu}(\mathrm{Cl})(\mathrm{IPr})](1 \mathrm{~g}, 2.05 \mathrm{mmol})$, 1,2,4-triazole $(155.8 \mathrm{mg}, 2.26 \mathrm{mmol})$ and $\mathrm{CsOH}(614.9 \mathrm{mg}, 4.1 \mathrm{mmol})$ in THF $(20 \mathrm{~mL})$ led to the isolation of $1 \mathbf{a}$ as a colorless solid in $90 \%$ isolated yield $(973 \mathrm{mg}) .{ }^{1} \mathbf{H}$ NMR $\left(500 \mathrm{MHz}, \mathrm{C}_{6} \mathrm{D}_{6}, 298 \mathrm{~K}\right): \delta(\mathrm{ppm})=7.24\left(\mathrm{t},{ }^{3} J_{\mathrm{H}-\mathrm{H}}=8.0 \mathrm{~Hz}, 4 \mathrm{H}, \mathrm{C}_{\mathrm{Ar}} \mathrm{H}\right)$, $7.05\left(\mathrm{~d},{ }^{3} \mathrm{~J}_{\mathrm{H}-\mathrm{H}}=8.0 \mathrm{~Hz}, 8 \mathrm{H}, \mathrm{C}_{\mathrm{Ar}} \mathrm{H}\right), 6.73(\mathrm{~s}, 4 \mathrm{H}, \mathrm{CH} \operatorname{trz}), 6.39(\mathrm{~s}, 4 \mathrm{H}$, $\mathrm{H}^{4}$ and $\mathrm{H}^{5}$ carbene), 2.83 (sept, $\left.{ }^{3} J_{\mathrm{H}-\mathrm{H}}=6.8 \mathrm{~Hz}, 8 \mathrm{H}, \mathrm{CH}\left(\mathrm{CH}_{3}\right)_{2}\right), 1.13$ $\left(\mathrm{d},{ }^{3} J_{\mathrm{H}-\mathrm{H}}=6.8 \mathrm{~Hz}, 24 \mathrm{H}, \mathrm{CH}\left(\mathrm{CH}_{3}\right)_{2}\right), 1.04\left(\mathrm{~d},{ }^{3} J_{\mathrm{H}-\mathrm{H}}=6.8 \mathrm{~Hz}, 24 \mathrm{H}\right.$, $\left.\mathrm{CH}\left(\mathrm{CH}_{3}\right)_{2}\right) \cdot{ }^{13} \mathbf{C}-\left\{{ }^{1} \mathbf{H}\right\}$ NMR $\left(126 \mathrm{MHz}, \mathrm{C}_{6} \mathrm{D}_{6}, 298 \mathrm{~K}\right): \delta(\mathrm{ppm})=189.2$ (s, $\mathrm{C}^{2}$ carbene), $152.1\left(\mathrm{~s}, \mathrm{CH}\right.$ trz), $146.4\left(\mathrm{~s}, \mathrm{C}^{\mathrm{IV}}\right), 137.4\left(\mathrm{~s}, \mathrm{C}^{\mathrm{IV}}\right), 131.0$ $\left(\mathrm{s}, \mathrm{C}_{\mathrm{Ar}} \mathrm{H}\right), 125.0\left(\mathrm{~s}, \mathrm{C}_{\mathrm{Ar}} \mathrm{H}\right), 122.8\left(\mathrm{~s}, \mathrm{C}^{4}\right.$ and $\mathrm{C}^{5}$ carbene), $29.4(\mathrm{~s}$, $\left.\mathrm{CH}\left(\mathrm{CH}_{3}\right)_{2}\right), 25.1$ (s, $\left.\mathrm{CH}\left(\mathrm{CH}_{3}\right)_{2}\right), 24.7\left(\mathrm{~s}, \mathrm{CH}\left(\mathrm{CH}_{3}\right)_{2}\right)$. Anal. Calcd. for $\mathrm{C}_{58} \mathrm{H}_{76} \mathrm{Cu}_{2} \mathrm{~N}_{10}$ : C, 66.96; H, 7.36; N, 13.45. Found: C, 66.77; H, 7.24; $\mathrm{N}, 13.33$.

Bis-\{[N,N-bis(2,6-(di-isopropyl)phenyl)imidazol-2-ylidene] $(1 \mathrm{H}$ -

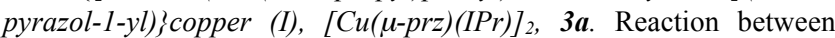
$[\mathrm{Cu}(\mathrm{Cl})(\mathrm{IPr})](1 \mathrm{~g}, 2.05 \mathrm{mmol}), 1 H$-pyrazole $(153.8 \mathrm{mg}, 2.26 \mathrm{mmol})$ and $\mathrm{CsOH}(614.9 \mathrm{mg}, 4.1 \mathrm{mmol})$ in THF $(20 \mathrm{~mL})$ led to the isolation of 3a as a colorless solid in $81 \%$ isolated yield $(863 \mathrm{mg}) .{ }^{1} \mathbf{H}$ NMR $\left(400 \mathrm{MHz}, \mathrm{C}_{6} \mathrm{D}_{6}, 298 \mathrm{~K}\right): \delta(\mathrm{ppm})=7.22\left(\mathrm{t},{ }^{3} J_{\mathrm{H}-\mathrm{H}}=7.5 \mathrm{~Hz}, 2 \mathrm{H}, \mathrm{C}_{\mathrm{Ar}} \mathrm{H}\right)$, $7.07\left(\mathrm{~d},{ }^{3} J_{\mathrm{H}-\mathrm{H}}=7.5 \mathrm{~Hz}, 4 \mathrm{H}, \mathrm{C}_{\mathrm{Ar}} \mathrm{H}\right), 6.75(\mathrm{~s}, 2 \mathrm{H}, \mathrm{CH}$ pyrazole), $6.46(\mathrm{~s}$, $2 \mathrm{H}, \mathrm{H}^{4}$ and $\mathrm{H}^{5}$ carbene $), 6.12(\mathrm{~s}, 1 \mathrm{H}, \mathrm{CH}$ pyrazole $), 3.14-2.96(\mathrm{~m}, 4 \mathrm{H}$, $\left.\mathrm{CH}\left(\mathrm{CH}_{3}\right)_{2}\right), 1.17\left(\mathrm{~d},{ }^{3} J_{\mathrm{H}-\mathrm{H}}=6.8 \mathrm{~Hz}, 12 \mathrm{H}, \mathrm{CH}\left(\mathrm{CH}_{3}\right)_{2}\right), 1.09\left(\mathrm{~d},{ }^{3} J_{\mathrm{H}-\mathrm{H}}=\right.$ $\left.6.8 \mathrm{~Hz}, 12 \mathrm{H}, \mathrm{CH}\left(\mathrm{CH}_{3}\right)_{2}\right) .{ }^{13} \mathbf{C}-\left\{{ }^{1} \mathbf{H}\right\}$ NMR $\left(100 \mathrm{MHz}, \mathrm{C}_{6} \mathrm{D}_{6}, 298 \mathrm{~K}\right): \delta$ $(\mathrm{ppm})=190.4\left(\mathrm{~s}, \mathrm{C}^{2}\right.$ carbene $), 146.6\left(\mathrm{~s}, \mathrm{C}^{\mathrm{IV}}\right), 139.2(\mathrm{~s}, \mathrm{CH}$ pyrazole $)$, $137.8\left(\mathrm{~s}, \mathrm{C}^{\mathrm{IV}}\right), 130.2\left(\mathrm{~s}, \mathrm{C}_{\mathrm{Ar}} \mathrm{H}\right), 128.9\left(\mathrm{~s}, \mathrm{C}_{\mathrm{Ar}} \mathrm{H}\right) 124.7\left(\mathrm{~s}, \mathrm{C}_{\mathrm{Ar}} \mathrm{H}\right), 122.5$ (s, $\mathrm{C}^{4}$ and $\mathrm{C}^{5}$ carbene), 100.5 (s, $\mathrm{CH}$ pyrazole), $29.3\left(\mathrm{~s}, \mathrm{CH}\left(\mathrm{CH}_{3}\right)_{2}\right)$, $25.7\left(\mathrm{~s}, \mathrm{CH}\left(\mathrm{CH}_{3}\right)_{2}\right), 24.4\left(\mathrm{~s}, \mathrm{CH}\left(\mathrm{CH}_{3}\right)_{2}\right)$.

Bis-\{[N,N'-bis(2,6-(di-isopropyl)phenyl)imidazol-2-ylidene](4methyl-pyrazol-1-yl)\}copper (I), $\left[\mathrm{Cu}\{\boldsymbol{\mu} \text {-(4Me-prz)\}(IPr) }]_{2}, \quad 3 \boldsymbol{b}\right.$. Reaction between $[\mathrm{Cu}(\mathrm{Cl})(\mathrm{IPr})](1 \mathrm{~g}, 2.05 \mathrm{mmol})$, 4-methyl-pyrazole $(186.8 \mu \mathrm{L}, 2.26 \mathrm{mmol})$ and $\mathrm{CsOH}(614.9 \mathrm{mg}, 4.1 \mathrm{mmol})$ in THF $(20$ $\mathrm{mL}$ ) led to the isolation of $\mathbf{3 b}$ as a colorless solid in $85 \%$ isolated yield (930 mg). ${ }^{1} \mathbf{H}$ NMR (500 MHz, $\left.\mathrm{C}_{6} \mathrm{D}_{6}, 298 \mathrm{~K}\right): \delta(\mathrm{ppm})=7.23(\mathrm{t}$, $\left.{ }^{3} J_{\mathrm{H}-\mathrm{H}}=7.6 \mathrm{~Hz}, 2 \mathrm{H}, \mathrm{C}_{\mathrm{Ar}} \mathrm{H}\right), 7.07\left(\mathrm{~d},{ }^{3} J_{\mathrm{H}-\mathrm{H}}=7.6 \mathrm{~Hz}, 4 \mathrm{H}, \mathrm{C}_{\mathrm{Ar}} \mathrm{H}\right), 6.46(\mathrm{~s}$, $2 \mathrm{H}, \mathrm{H}^{4}$ and $\mathrm{H}^{5}$ carbene), $6.43(\mathrm{~s}, 2 \mathrm{H}, \mathrm{CH}$ pyrazole $), 3.11-3.00(\mathrm{~m}, 4 \mathrm{H}$, $\left.\mathrm{C} H\left(\mathrm{CH}_{3}\right)_{2}\right), 2.21\left(\mathrm{~s}, 3 \mathrm{H}, \mathrm{CH}_{3}\right), 1.18\left(\mathrm{~d},{ }^{3} J_{\mathrm{H}-\mathrm{H}}=6.8 \mathrm{~Hz}, 12 \mathrm{H}\right.$, $\left.\mathrm{CH}\left(\mathrm{CH}_{3}\right)_{2}\right), 1.10\left(\mathrm{~d},{ }^{3} \mathrm{~J}_{\mathrm{H}-\mathrm{H}}=6.8 \mathrm{~Hz}, 12 \mathrm{H}, \mathrm{CH}\left(\mathrm{CH}_{3}\right)_{2}\right) .{ }^{13} \mathbf{C}-\left\{{ }^{1} \mathbf{H}\right\} \mathbf{~ N M R}$ $\left(126 \mathrm{MHz}, \mathrm{C}_{6} \mathrm{D}_{6}, 298 \mathrm{~K}\right): \delta(\mathrm{ppm})=190.5\left(\mathrm{~s}, \mathrm{C}^{2}\right.$ carbene $), 146.7(\mathrm{~s}$, $\left.\mathrm{C}^{\mathrm{IV}}\right), 139.8(\mathrm{~s}, \mathrm{CH}$ azole $), 138.0\left(\mathrm{~s}, \mathrm{C}^{\mathrm{IV}}\right), 130.1\left(\mathrm{~s}, \mathrm{C}_{\mathrm{Ar}} \mathrm{H}\right), 124.6(\mathrm{~s}$, $\left.\mathrm{C}_{\mathrm{Ar}} \mathrm{H}\right), 122.4\left(\mathrm{~s}, \mathrm{C}^{4}\right.$ and $\mathrm{C}^{5}$ carbene $), 109.5\left(\mathrm{~s}, \mathrm{C}^{\mathrm{IV}}\right), 29.3(\mathrm{~s}$, $\left.\mathrm{CH}\left(\mathrm{CH}_{3}\right)_{2}\right), 25.8\left(\mathrm{~s}, \mathrm{CH}\left(\mathrm{CH}_{3}\right)_{2}\right), 24.3\left(\mathrm{~s}, \mathrm{CH}\left(\mathrm{CH}_{3}\right)_{2}\right), 10.5\left(\mathrm{~s}, \mathrm{CH}_{3}\right)$. Anal. Calcd. for $\mathrm{C}_{31} \mathrm{H}_{41} \mathrm{CuN}_{4}$ : C, 69.83; H, 7.75; N, 10.51. Found: C, $69.83 ; \mathrm{H}, 7.81 ; \mathrm{N}, 10.54$

Bis-\{[N,N-bis(2,6-(di-isopropyl)phenyl)imidazol-2-ylidene](4bromo-pyrazol-1-yl)\}copper (I), $\quad[C u\{\mu-(4-B r-p r z)\}(I P r)]_{2}, \quad 3 c$ Reaction between $[\mathrm{Cu}(\mathrm{Cl})(\mathrm{IPr})](1 \mathrm{~g}, 2.05 \mathrm{mmol})$, 4-bromo-pyrazole (332.2 mg, $2.26 \mathrm{mmol})$ and $\mathrm{CsOH}(614.9 \mathrm{mg}, 4.1 \mathrm{mmol})$ in THF (20 $\mathrm{mL}$ ) led to the isolation of $\mathbf{3 c}$ as a colorless solid in $93 \%$ isolated yield $(1140 \mathrm{mg}) .{ }^{1} \mathbf{H}$ NMR $\left(500 \mathrm{MHz}, \mathrm{C}_{6} \mathrm{D}_{6}, 298 \mathrm{~K}\right): \delta(\mathrm{ppm})=7.35\left(\mathrm{t},{ }^{3} J_{\mathrm{H}-\mathrm{H}}\right.$ $\left.=7.8 \mathrm{~Hz}, 2 \mathrm{H}, \mathrm{C}_{\mathrm{Ar}} \mathrm{H}\right), 7.10\left(\mathrm{~d},{ }^{3} J_{\mathrm{H}-\mathrm{H}}=7.8 \mathrm{~Hz}, 4 \mathrm{H}, \mathrm{C}_{\mathrm{Ar}} \mathrm{H}\right), 6.39(\mathrm{~s}, 2 \mathrm{H}$, $\mathrm{H}^{4}$ and $\mathrm{H}^{5}$ carbene), $6.36(\mathrm{~s}, 1 \mathrm{H}, \mathrm{CH}$ azole $), 2.94-2.77(\mathrm{~m}, 4 \mathrm{H}$, $\left.\mathrm{CH}\left(\mathrm{CH}_{3}\right)_{2}\right), 1.14\left(\mathrm{~d},{ }^{3} J_{\mathrm{H}-\mathrm{H}}=6.8 \mathrm{~Hz}, 12 \mathrm{H}, \mathrm{CH}\left(\mathrm{CH}_{3}\right)_{2}\right), 1.05\left(\mathrm{~d},{ }^{3} J_{\mathrm{H}-\mathrm{H}}=\right.$ $\left.6.8 \mathrm{~Hz}, 12 \mathrm{H}, \mathrm{CH}\left(\mathrm{CH}_{3}\right)_{2}\right) .{ }^{13} \mathbf{C}-\left\{{ }^{1} \mathrm{H}\right\}$ NMR $\left(126 \mathrm{MHz}, \mathrm{C}_{6} \mathrm{D}_{6}, 298 \mathrm{~K}\right): \delta$ $(\mathrm{ppm})=189.2\left(\mathrm{~s}, \mathrm{C}^{2}\right.$ carbene $), 146.6\left(\mathrm{~s}, \mathrm{C}^{\mathrm{IV}}\right), 139.7(\mathrm{~s}, \mathrm{CH}$ azole $)$, $137.5\left(\mathrm{~s}, \mathrm{C}^{\mathrm{IV}}\right), 130.7\left(\mathrm{~s}, \mathrm{C}_{\mathrm{Ar}} \mathrm{H}\right), 128.9\left(\mathrm{~s}, \mathrm{C}^{\mathrm{IV}}\right), 124.9\left(\mathrm{~s}, \mathrm{C}_{\mathrm{Ar}} \mathrm{H}\right), 122.7$ (s, $\mathrm{C}^{4}$ and $\mathrm{C}^{5}$ carbene), $29.4\left(\mathrm{~s}, \mathrm{CH}\left(\mathrm{CH}_{3}\right)_{2}\right), 25.4\left(\mathrm{~s}, \mathrm{CH}\left(\mathrm{CH}_{3}\right)_{2}\right), 24.5$ (s, $\left.\mathrm{CH}\left(\mathrm{CH}_{3}\right)_{2}\right)$. Anal. Calcd. for $\mathrm{C}_{30} \mathrm{H}_{38} \mathrm{BrCuN}_{4}: \mathrm{C}, 60.24 ; \mathrm{H}, 6.40 ; \mathrm{N}$, 9.37. Found: C, 60.18; H, 6.47; N, 9.48.

[N,N-bis(2,6-(di-isopropyl)phenyl)imidazol-2-ylidene](3-methylpyrazol-1-yl)copper (I), [Cu(3-Me-prz)(IPr)], 3d. Reaction between $[\mathrm{Cu}(\mathrm{Cl})(\mathrm{IPr})](1 \mathrm{~g}, 2.05 \mathrm{mmol}), 3$-methyl-pyrazole $(182 \mu \mathrm{L}, 2.26$ $\mathrm{mmol})$ and $\mathrm{CsOH}(614.9 \mathrm{mg}, 4.1 \mathrm{mmol})$ in THF $(20 \mathrm{~mL})$ led to the isolation of $\mathbf{3 d}$ as a colorless solid in $92 \%$ isolated yield $(1007 \mathrm{mg})$. ${ }^{1} \mathbf{H}$ NMR $\left(500 \mathrm{MHz}, \mathrm{CD}_{2} \mathrm{Cl}_{2}, 298 \mathrm{~K}\right): \delta(\mathrm{ppm})=7.52\left(\mathrm{t},{ }^{3} J_{\mathrm{H}-\mathrm{H}}=7.7\right.$ $\left.\mathrm{Hz}, 2 \mathrm{H}, \mathrm{C}_{\mathrm{Ar}} \mathrm{H}\right), 7.34\left(\mathrm{~d},{ }^{3} \mathrm{~J}_{\mathrm{H}-\mathrm{H}}=7.7 \mathrm{~Hz}, 4 \mathrm{H}, \mathrm{C}_{\mathrm{Ar}} \mathrm{H}\right), 7.22\left(\mathrm{~s}, 2 \mathrm{H}, \mathrm{H}^{4}\right.$ and $\mathrm{H}^{5}$ carbene $), 7.01(\mathrm{~s}, 1 \mathrm{H}, \mathrm{CH}$ pyrazole $), 5.63(\mathrm{~s}, 1 \mathrm{H}, \mathrm{CH}$ pyrazole $)$, $2.61\left(\mathrm{sept},{ }^{3} J_{\mathrm{H}-\mathrm{H}}=6.8 \mathrm{~Hz}, 8 \mathrm{H}, \mathrm{CH}\left(\mathrm{CH}_{3}\right)_{2}\right), 1.72\left(\mathrm{~s}, 3 \mathrm{H}, \mathrm{CH}_{3}\right), 1.29(\mathrm{~d}$, $\left.{ }^{3} J_{\mathrm{H}-\mathrm{H}}=6.8 \mathrm{~Hz}, 12 \mathrm{H}, \mathrm{CH}\left(\mathrm{CH}_{3}\right)_{2}\right), 1.23\left(\mathrm{~d},{ }^{3} J_{\mathrm{H}-\mathrm{H}}=6.8 \mathrm{~Hz}, 12 \mathrm{H}\right.$, $\left.\mathrm{CH}\left(\mathrm{CH}_{3}\right)_{2}\right) .{ }^{13} \mathbf{C}-\left\{{ }^{1} \mathbf{H}\right\}$ NMR $\left(126 \mathrm{MHz}, \mathrm{CD}_{2} \mathrm{Cl}_{2}, 298 \mathrm{~K}\right): \delta(\mathrm{ppm})=$ $181.1\left(\mathrm{~s}, \mathrm{C}^{2}\right.$ carbene), $146.0\left(\mathrm{~s}, \mathrm{C}^{\mathrm{IV}}\right), 145.9\left(\mathrm{~s}, \mathrm{C}^{\mathrm{IV}}\right) 139.3(\mathrm{~s}, \mathrm{CH}$ azole $), 134.7\left(\mathrm{~s}, \mathrm{C}^{\mathrm{IV}}\right), 130.5\left(\mathrm{~s}, \mathrm{C}_{\mathrm{Ar}} \mathrm{H}\right), 124.3\left(\mathrm{~s}, \mathrm{C}_{\mathrm{Ar}} \mathrm{H}\right), 123.6\left(\mathrm{~s}, \mathrm{C}^{4}\right.$ and $\mathrm{C}^{5}$ carbene), $101.0\left(\mathrm{~s}, \mathrm{CH}\right.$ azole), $28.8\left(\mathrm{~s}, \mathrm{CH}\left(\mathrm{CH}_{3}\right)_{2}\right), 24.7$ (s, $\left.\mathrm{CH}\left(\mathrm{CH}_{3}\right)_{2}\right), 23.7\left(\mathrm{~s}, \mathrm{CH}\left(\mathrm{CH}_{3}\right)_{2}\right), 12.9$ (s, $\left.\mathrm{CH}_{3}\right)$. Anal. Calcd. for $\mathrm{C}_{31} \mathrm{H}_{41} \mathrm{CuN}_{4}$ : C, 69.83; H, 7.75; N, 10.51. Found: C, 69.69; H, 7.75; $\mathrm{N}, 10.67$.

[N,N'-bis(2,6-(di-isopropyl)phenyl)imidazol-2-ylidene](3-bromopyrazol-1-yl)copper (I), [Cu(3-Br-prz)(IPr)], 3e. Reaction between $[\mathrm{Cu}(\mathrm{Cl})(\mathrm{IPr})](1 \mathrm{~g}, 2.05 \mathrm{mmol}), 3$-bromo-pyrazole $(332.2 \mathrm{mg}, 2.26$ $\mathrm{mmol})$ and $\mathrm{CsOH}(614.9 \mathrm{mg}, 4.1 \mathrm{mmol})$ in THF $(20 \mathrm{~mL})$ led to the isolation of $3 \mathbf{e}$ as a colorless solid in $90 \%$ isolated yield $(1103 \mathrm{mg})$. ${ }^{1} \mathrm{H}$ NMR $\left(500 \mathrm{MHz}, \mathrm{C}_{6} \mathrm{D}_{6}, 298 \mathrm{~K}\right): \delta(\mathrm{ppm})=7.45(\mathrm{~s}, 1 \mathrm{H}, \mathrm{CH}$ pyrazole), $7.16\left(\mathrm{t},{ }^{3} J_{\mathrm{H}-\mathrm{H}}=7.7 \mathrm{~Hz}, 2 \mathrm{H}, \mathrm{C}_{\mathrm{Ar}} \mathrm{H}\right), 7.02\left(\mathrm{~d},{ }^{3} J_{\mathrm{H}-\mathrm{H}}=7.7 \mathrm{~Hz}\right.$, $\left.4 \mathrm{H}, \mathrm{C}_{\mathrm{Ar}} \mathrm{H}\right), 6.28(\mathrm{~s}, 1 \mathrm{H}, \mathrm{CH}$ pyrazole $), 6.25\left(\mathrm{~s}, 2 \mathrm{H}, \mathrm{H}^{4}\right.$ and $\mathrm{H}^{5}$ carbene), $2.53\left(\mathrm{sept},{ }^{3} J_{\mathrm{H}-\mathrm{H}}=6.9 \mathrm{~Hz}, 4 \mathrm{H}, \mathrm{CH}\left(\mathrm{CH}_{3}\right)_{2}\right), 1.34\left(\mathrm{~d},{ }^{3} J_{\mathrm{H}-\mathrm{H}}=\right.$ $\left.6.9 \mathrm{~Hz}, 12 \mathrm{H}, \mathrm{CH}\left(\mathrm{CH}_{3}\right)_{2}\right), 1.05\left(\mathrm{~d},{ }^{3} J_{\mathrm{H}-\mathrm{H}}=6.9 \mathrm{~Hz}, 12 \mathrm{H}, \mathrm{CH}\left(\mathrm{CH}_{3}\right)_{2}\right)$. ${ }^{13} \mathbf{C}-\left\{{ }^{1} \mathbf{H}\right\}$ NMR $\left(126 \mathrm{MHz}, \mathrm{C}_{6} \mathrm{D}_{6}, 298 \mathrm{~K}\right): \delta(\mathrm{ppm})=182.6\left(\mathrm{~s}, \mathrm{C}^{2}\right.$ carbene), $146.3\left(\mathrm{~s}, \mathrm{C}^{\mathrm{IV}}\right), 141.5(\mathrm{~s}, \mathrm{CH}$ azole $), 135.3\left(\mathrm{~s}, \mathrm{C}^{\mathrm{IV}}\right), 131.4(\mathrm{~s}$, $\left.\mathrm{C}_{\mathrm{Ar}} \mathrm{H}\right), 125.0\left(\mathrm{~s}, \mathrm{C}_{\mathrm{Ar}} \mathrm{H}\right), 123.5\left(\mathrm{~s}, \mathrm{C}^{4}\right.$ and $\mathrm{C}^{5}$ carbene $), 123.0\left(\mathrm{~s}, \mathrm{C}^{\mathrm{IV}}\right.$ azole), 105.0 (s, $\mathrm{CH}$ azole), $29.6\left(\mathrm{~s}, \mathrm{CH}\left(\mathrm{CH}_{3}\right)_{2}\right), 25.7\left(\mathrm{~s}, \mathrm{CH}\left(\mathrm{CH}_{3}\right)_{2}\right)$, 24.4 (s, $\left.\mathrm{CH}\left(\mathrm{CH}_{3}\right)_{2}\right)$. Anal. Calcd. $\mathrm{C}_{30} \mathrm{H}_{38} \mathrm{BrCuN}_{4}$ : C, 60.24; H, 6.40; $\mathrm{N}, 9.37$. Found: C, 60.18; H, 6.31; N, 9.38.

[N,N'-bis(2,6-(di-isopropyl)phenyl)imidazol-2-ylidene](indazol-1yl)copper (I), [Cu(ind)(IPr)], $3 f$. Reaction between $[\mathrm{Cu}(\mathrm{Cl})(\mathrm{IPr})](1 \mathrm{~g}$, $2.05 \mathrm{mmol}$ ), indazole (267 mg, $2.26 \mathrm{mmol})$ and $\mathrm{CsOH}(614.9 \mathrm{mg}, 4.1$ $\mathrm{mmol})$ in THF $(20 \mathrm{~mL})$ led to the isolation of $\mathbf{3 f}$ as a colorless solid in $94 \%$ isolated yield (1098 mg). ${ }^{1} \mathbf{H}$ NMR (500 MHz, $\left.\mathrm{CD}_{2} \mathrm{Cl}_{2}, 298 \mathrm{~K}\right): \delta$ $(\mathrm{ppm})=7.77\left(\mathrm{~d},{ }^{5} J_{\mathrm{H}-\mathrm{H}}=1.1 \mathrm{~Hz}, 1 \mathrm{H}, \mathrm{CH}\right.$ azole $), 7.59\left(\mathrm{t},{ }^{3} J_{\mathrm{H}-\mathrm{H}}=7.8 \mathrm{~Hz}\right.$, $\left.2 \mathrm{H}, \mathrm{C}_{\mathrm{Ar}} \mathrm{H}\right), 7.46\left(\mathrm{dt},{ }^{3} J_{\mathrm{H}-\mathrm{H}}=7.8 \mathrm{~Hz},{ }^{5} J_{\mathrm{H}-\mathrm{H}}=1.1 \mathrm{~Hz}, 1 \mathrm{H}, \mathrm{CH}\right.$ azole $)$, $7.39\left(\mathrm{~d},{ }^{3} J_{\mathrm{H}-\mathrm{H}}=7.8 \mathrm{~Hz}, 4 \mathrm{H}, \mathrm{C}_{\mathrm{Ar}} \mathrm{H}\right), 7.27\left(\mathrm{~s}, 2 \mathrm{H}, \mathrm{H}^{4}\right.$ and $\mathrm{H}^{5}$ carbene), 6.82-6.76 (m, 1H, CH azole), 6.74-6.69 (m, 1H, CH azole), $6.32(\mathrm{~d}$, ${ }^{3} J_{\mathrm{H}-\mathrm{H}}=8.3 \mathrm{~Hz}, 1 \mathrm{H}, \mathrm{CH}$ azole), 2.67 (sept, ${ }^{3} J_{\mathrm{H}-\mathrm{H}}=6.8 \mathrm{~Hz}, 8 \mathrm{H}$, $\left.\mathrm{CH}\left(\mathrm{CH}_{3}\right)_{2}\right), 1.31\left(\mathrm{~d},{ }^{3} J_{\mathrm{H}-\mathrm{H}}=6.8 \mathrm{~Hz}, 12 \mathrm{H}, \mathrm{CH}\left(\mathrm{CH}_{3}\right)_{2}\right), 1.26\left(\mathrm{~d},{ }^{3} J_{\mathrm{H}-\mathrm{H}}=\right.$ $\left.6.8 \mathrm{~Hz}, 12 \mathrm{H}, \mathrm{CH}\left(\mathrm{CH}_{3}\right)_{2}\right) .{ }^{13} \mathbf{C}-\left\{{ }^{1} \mathbf{H}\right\} \mathbf{N M R}\left(126 \mathrm{MHz}, \mathrm{CD}_{2} \mathrm{Cl}_{2}, 298 \mathrm{~K}\right)$ : $\delta(\mathrm{ppm})=181.0\left(\mathrm{~s}, \mathrm{C}^{2}\right.$ carbene $), 150.0\left(\mathrm{~s}, \mathrm{C}^{\mathrm{IV}}\right), 146.0\left(\mathrm{~s}, \mathrm{C}^{\mathrm{IV}}\right.$ azole $)$, $134.7\left(\mathrm{~s}, \mathrm{C}^{\mathrm{IV}}\right), 133.1(\mathrm{~s}, \mathrm{CH}$ azole $), 130.6\left(\mathrm{~s}, \mathrm{C}_{\mathrm{Ar}} \mathrm{H}\right), 124.4\left(\mathrm{~s}, \mathrm{C}_{\mathrm{Ar}} \mathrm{H}\right)$, $123.6\left(\mathrm{~s}, \mathrm{C}^{4}\right.$ and $\mathrm{C}^{5}$ carbene, $123.1\left(\mathrm{~s}, \mathrm{C}^{\mathrm{IV}}\right.$ azole), 122.2 (s, $\mathrm{CH}$ azole), 119.3 (s, CH azole), 117.4 (s, $\mathrm{CH}$ azole), 112.9 (s, CH azole), 28.9 (s, $\left.\mathrm{CH}\left(\mathrm{CH}_{3}\right)_{2}\right), 24.7\left(\mathrm{~s}, \mathrm{CH}\left(\mathrm{CH}_{3}\right)_{2}\right), 23.6\left(\mathrm{~s}, \mathrm{CH}\left(\mathrm{CH}_{3}\right)_{2}\right)$. Anal. Calcd. for $\mathrm{C}_{34} \mathrm{H}_{41} \mathrm{CuN}_{4}$ : C, 71.74; H, 7.26; N, 9.84. Found: C, 71.64; H, 7.40; N, 9.87.

Synthesis of [N,N'-bis(2,6-(di-isopropyl)phenyl)imidazol-2ylidene](1-phenylethoxy)copper (I), [Cu(1-phenylethoxy)(IPr)], 6. In a glovebox, into a $20 \mathrm{~mL}$ scintillation vial $\left[\mathrm{Cu}\left(\mathrm{O}^{t} \mathrm{Bu}\right)(\mathrm{IPr})\right](300 \mathrm{mg}$, 1.0 equiv.) was dissolved in $5 \mathrm{~mL}$ of benzene and 1-phenylethanol (1.1 equiv.) was added. The reaction was stirred at $25{ }^{\circ} \mathrm{C}$ for $16 \mathrm{~h}$. The mixture was concentrated in vacuo until formation of a precipitate. Hexane $(5 \mathrm{~mL})$ was added. The precipitate was collected by filtration, washed with hexane $(2 \times 5 \mathrm{~mL})$ and dried in vacuo to 
yield $\mathbf{6}$ as a colorless solid in $83 \%$ isolated yield $(271 \mathrm{mg}) .{ }^{1} \mathbf{H}$ NMR $\left(500 \mathrm{MHz}, \mathrm{C}_{6} \mathrm{D}_{6}, 298 \mathrm{~K}\right): \delta(\mathrm{ppm})=7.52\left(\mathrm{~d}, 3 \mathrm{JH}_{-\mathrm{H}}=7.7 \mathrm{~Hz}, 2 \mathrm{H}\right.$, $\left.\mathrm{C}_{\mathrm{Ar}} \mathrm{H}\right), 7.24-7.16\left(\mathrm{~m}, 4 \mathrm{H}, \mathrm{C}_{\mathrm{Ar}} \mathrm{H}\right), 7.10\left(\mathrm{t}, 3 \mathrm{~J}_{\mathrm{H}-\mathrm{H}}=7.3 \mathrm{~Hz}, 2 \mathrm{H}, \mathrm{C}_{\mathrm{Ar}} \mathrm{H}\right)$, $7.05\left(\mathrm{~d}, 3 \mathrm{~J}_{\mathrm{H}-\mathrm{H}}=7.7 \mathrm{~Hz}, 2 \mathrm{H}, \mathrm{C}_{\mathrm{Ar}} \mathrm{H}\right), 6.25\left(\mathrm{~s}, 2 \mathrm{H}, \mathrm{H}^{4}\right.$ and $\mathrm{H}^{5}$ carbene $)$, 5.29 (bs, $1 \mathrm{H}, \mathrm{CH}), 2.55$ (sept, $\left.3 \mathrm{~J}_{\mathrm{H}-\mathrm{H}}=7.0 \mathrm{~Hz}, 4 \mathrm{H}, \mathrm{CH}\left(\mathrm{CH}_{3}\right)_{2}\right), 1.37$ (d, $\left.3 \mathrm{~J}_{\mathrm{H}-\mathrm{H}}=6.3 \mathrm{~Hz}, 3 \mathrm{H}, \mathrm{CH}_{3}\right), 1.33\left(\mathrm{~d}, 3 \mathrm{~J}_{\mathrm{H}-\mathrm{H}}=7.0 \mathrm{~Hz}, 12 \mathrm{H}, \mathrm{CH}\left(\mathrm{CH}_{3}\right)_{2}\right)$, $1.05\left(\mathrm{~d}, 3 \mathrm{~J}_{\mathrm{H}-\mathrm{H}}=7.0 \mathrm{~Hz}, 12 \mathrm{H}, \mathrm{CH}\left(\mathrm{CH}_{3}\right)_{2}\right) .{ }^{13} \mathbf{C}-\left\{{ }^{1} \mathbf{H}\right\}$ NMR $(126 \mathrm{MHz}$, C6D6, 298K): $\delta(\mathrm{ppm})=184.0\left(\mathrm{~s}, \mathrm{C}^{2}\right.$ carbene $), 156.1\left(\mathrm{~s}, \mathrm{C}^{\mathrm{IV}}\right), 146.3$ $\left(\mathrm{s}, \mathrm{C}^{\mathrm{IV}}\right), 135.9\left(\mathrm{~s}, \mathrm{C}^{\mathrm{IV}}\right), 131.1\left(\mathrm{~s}, \mathrm{C}_{\mathrm{Ar}} \mathrm{H}\right), 128.2\left(\mathrm{~s}, \mathrm{C}_{\mathrm{Ar}} \mathrm{H}\right), 126.7(\mathrm{~s}$, $\left.\mathrm{C}_{\mathrm{Ar}} \mathrm{H}\right), 125.5\left(\mathrm{~s}, \mathrm{C}^{\mathrm{IV}}\right), 124.8\left(\mathrm{~s}, \mathrm{C}_{\mathrm{Ar}} \mathrm{H}\right), 123.0\left(\mathrm{~s}, \mathrm{C}^{4}\right.$ and $\mathrm{C}^{5}$ carbene $)$, 74.3 (s, $\mathrm{CH}), 34.0\left(\mathrm{~s}, \mathrm{CH}_{3}\right), 29.5\left(\mathrm{~s}, \mathrm{CH}\left(\mathrm{CH}_{3}\right)_{2}\right), 25.4\left(\mathrm{~s}, \mathrm{CH}\left(\mathrm{CH}_{3}\right)_{2}\right)$, $24.4\left(\mathrm{~s}, \mathrm{CH}\left(\mathrm{CH}_{3}\right)_{2}\right)$. Anal. Calcd. for $\mathrm{C}_{35} \mathrm{H}_{45} \mathrm{CuN}_{2} \mathrm{O}: \mathrm{C}, 73.33 ; \mathrm{H}, 7.91$; N, 4.89. Found: C, 73.22; H, 8.01; N, 4.93.

\section{ASSOCIATED CONTENT}

\section{Supporting Information}

Experimental details, characterization data, X-ray crystallography data for 3a-3f, $6{ }^{23}$ This material is available free of charge via the Internet at http://pubs.acs.org.

\section{AUTHOR INFORMATION}

\section{Corresponding Author}

*Professor Catherine S. J. Cazin: Catherine.Cazin@UGent.be

\section{Notes}

The authors declare no competing financial interests.

\section{ACKNOWLEDGMENT}

The authors gratefully acknowledge the Royal Society (University Research Fellowship to C.S.J.C.), the Spanish MINECO (CTQ2014-59832-JIN) and EU (FEDER fund UNGI08-4E-003) for funding.

\section{REFERENCES}

(1) For selected review on copper(I)-NHC applications see (a) Lazreg, F.; Nahra, F.; Cazin, C. S. J. Coord. Chem. Rev. 2015, $293-$ 294, 48-79; (b) Zhang, L.; Hou, Z. Pure Appl. Chem. 2012, 84, 17051712; (c) Zhang, L.; Hou, Z. Chem. Sci. 2013, 4, 3395-3403.

(2).For selected examples of mononuclear $[\mathrm{Cu}(\mathrm{X})(\mathrm{NHC})]$ see (a) Vergote, T.; Nahra, F.; Welle, A.; Luhmer, M.; Wouters, J.; Mager, N.; Riant, O.; Leyssens T. Chem. Eur. J. 2012, 18, 793-798; (b) Mankad, N. P.; Gray, T. G.; Laitar, D. S.; Sadighi J. P. Organometallics 2004, 23, 1191-1193; (c) Díez-González, S.; Escudero-Adán, E. C.; Benet-Buchholz, J.; Stevens, E. D.; Slawin, A. M. Z.; Nolan, S. P. Dalton Trans. 2010, 39, 7595-7606; (d) Santoro, O.; Collado, A.; Slawin, A. M. Z.; Nolan S. P.; Cazin, C. S. J. Chem. Commun. 2013, 49, 10483-10485; (e) Fortman, G. C.; Slawin, A. M. Z.; Nolan, S. P. Organometallics 2010, 29, 3966-3972; (f) Laitar, D. S.; Müller, P.; Sadighi, J. P. J. Am. Chem. Soc. 2005, 127, 1719617197; (g) Albright, A.; Gawley, R. E. J. Am. Chem. Soc. 2011, 133, 19680-19683; (h) Jordan, A. J.; Lalic, G.; Sadighi, J. P. Chem. Rev. 2016, 116, 8318-8372.

(3) For selected examples of mononuclear $\left[\mathrm{Cu}(\mathrm{NHC})_{2}\right] \mathrm{X}$ see (a) Díez-González, S.; Stevens, E. D.; Scott, N. M.; Petersen, J. L.; Nolan, S. P. Chem. Eur. J. 2008, 14, 158-168; (b) Lazreg, F.; Slawin, A. M. Z.; Cazin, C. S. J. Organometallics 2012, 31, 7969-7975; (c) Lazreg, F.; Cordes, D. B.; Slawin, A. M. Z.; Cazin, C. S. J. Organometallics 2015, 34, 419-425.

(4) Wyss, C. M.; Tate, B. K.; Bacsa, J.; Gray, T. G.; Sadighi, J. P. Angew. Chem. Int. Ed. 2013, 52, 12920-12923.
(5) Wyss, C. M.; Tate, B. K.; Bacsa, J.; Wieliczko, M.; Sadighi, J. P. Polyhedron 2014, 84, 87-95.

(6) Suess, A. M.; Uehling, M. R.; Kaminsky, W.; Lalic, G. J. Am. Chem. Soc. 2015, 137, 7747-7753.

(7) Wyss, C. M.; Bitting, J.; Bacsa, J.; Gray, T. G.; Sadighi, J. P. Organometallics 2016, 35, 71-74.

(8) Sgro, M. J.; Piers, W. E.; Romero, P. E. Dalton Trans. 2015, 44, 3817-3828; (b) Plotzitzka, J.; Kleeberg, C. Inorg. Chem. 2016, 55, 4813-4823.

(9) (a) Zhang, S.; Warren, T. H. Chem. Sci. 2013, 4, 1786-1792; (b) Fard, M. A.; Weigend, F.; Corrigan, J. F. Chem. Commun. 2015, 51, 8361-8364; (c) Fard, M. A.; Levchenko, T. I.; Cadogan, C.; Humenny, W. J.; Corrigan, J. F. Chem. Eur. J. 2016, 22, 4543-4550; (d) Zhai, J.; Filatov, A. S.; Hillhouse, G. L.; Hopkins, M. D. Chem. Sci. 2016, 7, 589-595.

(10) Dodds, C. A.; Kennedy, A. R. Z. Anorg. Allg. Chem. 2014, 640, 926-930.

(11) Trose, M.; Lazreg, F.; Chang, T.; Nahra, F.; Cordes, D. B.; Slawin, A. M. Z.; Cazin, C. S. J. ACS Catal. 2017, 7, 238-242.

(12) NMR spectra of $\mathbf{3 b} \mathbf{b}-\mathbf{3 f}$ after 6 months of storage in air did not show any trace of decomposition. Elemental analysis of 3a was not possible to perform due to its high air sensitivity.

(13) For selected examples of copper(I) catalyzed hydrosilylation of ketone with ligands different from NHCs see: (a) Lipshutz, B. H.; Noson, K.; Chrisman, W.; Lower, A. J. Am. Chem. Soc. 2003, 125, 8779-8789; (b) Lipshutz, B. H.; Noson, K.; Chrisman, W. J. Am. Chem. Soc. 2001, 123, 12917-12918; (c) Sirol, S.; Courmarcel, J.; Mostefaï, N.; Riant, O. Org. Lett. 2001, 3, 4111-4113; (d) Lipshutz, B. H.; Lower, A.; Noson, K. Org. Lett., 2002, 4, 4045-4048; (e) Lipshutz, B. H.; Chrisman, W.; Noson, K. J. Organomet. Chem. 2001, 624, 367-371; (f) Lipshutz, B. H.; Caires, C. C.; Kuipers, P.; Chrisman, W. Org. Lett. 2003, 5, 3085-3088; (g) Issenhuth, J. T.; Dagorne, S.; Bellemin-Laponnaz, S. Adv. Synth. Catal. 2006, 348, 1991-1994; (h) Junge, K.; Wendt, B.; Addis, D.; Zhou, S.; Das, S.; Beller, M. Chem. Eur. J. 2010, 16, 68-73; (i) Fujihara, T.; Semba, K.; Terao, J.; Tsuji, Y. Angew. Chem. Int. Ed. 2010, 49, 1472-1476; (j) Mostefaï, N.; Sirol, S.; Courmarcel, J.; Riant, O. Synthesis 2007, 8, 1265-1271.

(14) (a) Kaur, H.; Zinn, F. K.; Stevens, E. D.; Nolan, S. P. Organometallics 2004, 23, 1157-1160; (b) Díez-González, S.; Kaur, H.; Zinn, F. K.; Stevens, E. D.; Nolan, S. P. J. Org. Chem. 2005, 70, 4784-4796; (c) Díez-González, S.; Scott, N. M.; Nolan, S. P. Organometallics 2006, 25, 2355-2358; (d) Díez-González, S.; Nolan, S. P. Acc. Chem. Res. 2008, 41, 349-358;

(15) (a) Dong, L.; Qin, S.; Yang, H.; Su, Z.; Hu, C. Catal. Sci. Technol. 2012, 2, 564-569; (b) Vergote, T.; Nahra, F.; Merschaert, A.; Riant, O.; Peeters, D.; Leyssens, T. Organometallics 2014, 33, 19531963.

(16) Evans, R.; Deng, Z.; Rogerson, A. K.; McLachlan, A. S.; Richards, J. J.; Nilsson M.; Morris, G. A. Angew. Chem. Int. Ed. 2013, 52, 3199-3202.

(17) Mankad, N. P.; Laitar, D. S.; Sadighi J. P. Organometallics 2004, 23, 3369-3371.

(18) Vergote, T.; Nahra, F.; Peeters, D.; Riant, O.; Leyssens, T. J. Organomet. Chem. 2013, 730, 95-103;

(19) We used TMS-trz as a silylated triazole that could mimic the silylated by-product, $\mathrm{Me}(\mathrm{OEt})_{2} \mathrm{Si}$-trz, since procedures for the synthesis of the latter compound are not known up to date. Therefore, mechanistic tests involving this species do not model the exact catalytic conditions.

(20) (a) Falivene, L.; Credendino, R.; Poater, A.; Petta, A.; Serra, L.; Oliva, R.; Scarano, V.; Cavallo, L. Organometallics 2016, 35, 2286-2293. (b) Poater, A.; Cosenza, B.; Correa, A.; Giudice, S.; Ragone, F.; Scarano, V.; Cavallo, L. Eur. J. Inorg. Chem. 2009, 1759- 
1766.

(21) Ahmed, S. M.; Poater, A.; Childers, M. I.; Widger, P. C. B.; LaPointe, A. M.; Lobkovsky, E. B.; Coates, G. W.; Cavallo, L. J. Am. Chem. Soc. 2013, 135, 18901-18911.

(22) Czerwinski, P.; Molga, E.; Cavallo, L.; Poater, A.; Michalak, M. Chem. Eur. J. 2016, 22, 8089-8094.

(23) CCDC 1541291 (3a), CCDC 1541292 (3b), CCDC 1541293 (3c), CCDC 1541294 (3d), CCDC 1541295 (3e), CCDC 1541296 (3f) and CCDC 1541290 (6) contain the supplementary crystallographic data. These data can be obtained free of charge from the Cambridge Crystallographic Data

Centre

www.ccdc.cam.ac.uk/data request/cif. 
Graphical TOC

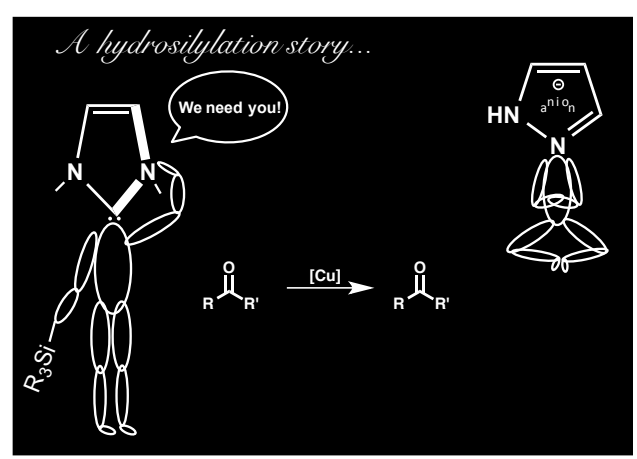

10 